\title{
Stefan Ciesielski
}

\section{Wniesienie apelacji w kanonicznym procesie o nieważność małżeństwa}

Prawo Kanoniczne : kwartalnik prawno-historyczny 30/3-4, 189-202

1987

Artykuł został zdigitalizowany i opracowany do udostępnienia w internecie przez Muzeum Historii Polski w ramach prac podejmowanych na rzecz zapewnienia otwartego, powszechnego i trwałego dostępu do polskiego dorobku naukowego i kulturalnego. Artykuł jest umieszczony w kolekcji cyfrowej bazhum.muzhp.pl, gromadzącej zawartość polskich czasopism humanistycznych i społecznych.

Tekst jest udostępniony do wykorzystania w ramach dozwolonego użytku. 


\section{KS. STEFAN CIESIELSKI}

\section{WNIESIENIE APELACJI \\ W KANONICZNYM PROCESIE O NIEWAŹNOSC MAZŹENSTWA}

Treśc: Wstęp. - 1. Geneza i pojęcie apelacji kanonicznej. - 2. Zgloszenie i poparcie apelacji. - 3. Przesłanie akt do trybunału apelacyjnego. - Zakończenie.

\section{Wstęp}

Sądowe rozstrzygnięcie sporu między dwiema stronami co do przysługujących im praw dokonuje się za pomocą wyroku. Wyrok sądowy, będący następstwem rozpoznania sporu zgodnie z przepisami prawa procesowego, jest prawnym środkiem wymiaru sprawiedliwości. Wyrok więc pelni szczególnie ważną i niezastąpioną rolę w życiu społecznym.

Wyrok sądorwy, aby mógł spełnić swoją rolę społeczną, musi być sprawiedliwy czyli opierać się na prawdzie obiektywnej. Do prawdy obiektywnej, która jest przedmiotem poszukiwań sądu i stanowi podstawe sprawiedliwego wyroku, dochodzi się w wyniku żmudnych i zlożonych czynności procesowych, przede wszystkim zaś wszechstronnego zbadania wszystkich okoliczności sprawy, sumiennego zebrania środków dowodowych oraz wlaściwej oceny argumentów przemawiających na korzyść i niekorzyść zarówno strony powodowej jak i strony pozwanej.

Poszukiwanie prawdy obiektywnej, zgodnie z przepisami prawa, przeprowadza sędzia. Jest on wyposażony ow autorytet władzy, jednakże jego własne przekonanie i sumienie $w$ istotny sposób rzutuje na wynik poszukiwań sądowych. Stąd każda sprawa sądıwa ma aspekt subiektywny. Prawidłowe rozpatrzenie sprawy powinno sędziego prowadzić do wnioskón obiektywnych, które, dzięki pewności sędziego o ich prawidłowym wyprowadzeniu, stają się jego własnym przekonaniem (zob. kan. 1608). Mimo to wyprowadzenie wniosków obiektywnych niekiedy jest narażone na niebezpieczeństwo subiektywizmu, który może prowadzić do naruszenia prawdy obiektywnej, w mastępstwie czego wyrok nie może być sprawiedliwy.

Prawnodawca kościelny odpowiednimi przepisami procesowymi starał się zagwarantować sprawiedliwość każdego wyroku sądowego. Ale też przewidział możliwość wydania wyroku niesprawiedliwego przez sędziego niższego. Chiąc zaradzić takiej sytuacji przyznal stronie pokrzywdzonej wyrokiem, jej zdaniem niespra- 
wiedliwym, prawo do apelacji czyli odwołania się do sędziego wyższego w celu naprawienia błędów sędziego niżśzeg.o. Dzięki apelacji $w$ sposób maksymalny zapewnia się wyrokowi sądowemu abiektywny i racjonalny charakter.

Przedmiotem niniejszej pracy będzie problematyka związana $\mathrm{z}$ wniesieniem apelacji w sprawach o nieważność małżeństwa. Problematyka ta jest ważna $z$ punktu widzenia zarówno naukowego, jak i praktyki procesowej. Postępowanie apelacyjne po Soborze Watykańskism II uległo stosunkowo dużym zmianom; zmiany te Kodeks Prawa Kanonicznego z 1983 r. włączył do swojego systemu.

\section{Geneza i pojęcie apelacji kanonicznej}

\section{a. Geneza apelacji}

Klasyczne prawo rzymsikie nie znało właściwej apelacji sadowej. W rzymskim postępowamiu zwyczajnym apelacja w ścisłym znaczeniu nié byla znana. Przeciwko decyzji magistnatury lub wyrokowi sądu przysługiwały jedynie niektóre środki prawne, np. prizywróceniie do stanu poprzedniego (restitutio in integrum), podjęcie powódiztwa egzekucyjnego (actio iudicati). Srodki te stanowiły surogat apelacji. Dapiero $w$ okresie cesarstwa, czyli w procesie kognicyjnym, strony mogły domagać się powtórnego nozpatrzenia sprawy przez sąd wyższy w celu naprawienia blędów wyrokowania popelnionych przez sędziów nizsszych. Apelarja niekiedy była wielostopmioma. Cesarz Justynian I (j27-56j) ograniczy liczbę apelacji oraz ustalił hierarchię sędziów, ustanawiając spec:alne normy proceduralne, które dały początek dzisiejszemu systemowi różnych instancji sądorwych 1.

Instytucja apelacji w kanonicznym prawie procesowym pojawiła się pod wpływem praktyki rzymskiej. Trzeba jednak stwierdzić, że w pierwszyıch wiekach chrześcijaństima rzadko korzystano $w$ Kościele $z$ apelacji. Wynikało to $z$ patriarchalnego charakteru pierwornego sądu biskupiego. Biskup rozstrzygał sprawy nie jako surawy sędzia, lecz raczej jako spramiedliwy ojciec, chrześcijanie zaś, zawsze posłuszni wobec biskupa, z uległością przyjmowali jego wyroki 2. Z czasem jednak, gdy liczba spraw sądowych wzrosła, przez co pormyłki sędziów mogły się zdiarzać częściej, apelacja stała się zwyczajnym środkiem odwohawczym od wyroków kościelnych. Od wyroku biskupa można byla apelować do sądu biskupów

${ }^{1}$ C., 7, 70. - Zob. W. Os u chow ski, Zarys rzymskiego prawa prywatnego, Warszawa $1966^{2}$, s. 188-189, 214; W. Li te wski, Wybrane zagadnienia rzymskiej apelacji, Kraków 1967 (Zeszyty Nlaukowe UJ 161).

2 Zob. T. P aw 1 u k, Kanoniczny proces karny, Warszawa 1978, s. 32. 
sąsiednich, do metropolity, prymasa prowincji, synodu prowincjonalnego, patriarchy, wreszcie do samego papież, nawet z pominięciem instancji pośredinich ${ }^{3}$. Prawo do apelacji wywodzono z zasady słuszności maturalnej. Dlatego dość wcześnie w prawie kościelnym pojiawił się nakaz przyjmowania wniesionej apelacji 4. $\mathrm{Tu}$ i ówdzie pod wplywem prawa rzymsktiego niekiedy usiłowano odwołać się od wyroku sędziego kościelnego do cesarza. Takie odwołanie uważano za nadużycie 5 . Katolikiowi nie wolno było apelować do sędziego innej wiary ${ }^{6}$. Bezpodistawne wniesienie apelacji było karalne 7 .

Najwyższym trybunałem apelacyjnym w Kościele od początku był sąd Biskupa Rzymskiego. Znane są ikanony synodu w Sardyce, odbytego w 343 r., które jednoznacznie podkreśliły tradycyjne prawo papieża do rozstrzygania spraw wplywających z całego Kościola w drodze apelacyjnej 8 . Biskupi zebrani na tym synodzie $w$ liście do papieża Juliusza I oświadczyli: „Wydaje się rzeczą dobrą i najbardziej wsklazamą, aby ze wszystkilch prowincji kapłani zwracali się do głowy Kościoła, tj. do Stolicy Apostoła Piotra" 9. Papież Bonifary I (418-422) w liście do Rufusa, biskupa Tesaloniki, zamieścił znamienme słowa: „Do synodu w Koryncie... wysłaliśmy takie pisma, aby iwszyscy bracia zrozumieli..., że nie należy odwolywać naszego wyroku. Nigdy bowiem nie bylo wolno roztrząsać na nowo tego, co zostało raz postanowicne przez Stolice Apostolską" 10. Slynne są slowa Św. Augustyna (354-430): Roma locuta, causa finita est 11; są cne dowodem uznawania Stolicy Apostalskiej za instancję najwyższą także w sprawach sądowych.

Kanonilczne prawo procesowe dopuszczając apelacje jednocześnie stairało się ograniczyć jich liczbę, aby spór nie proewlekał się zbytnio. Symod odbyty w Ant:ochii okolo 332 r. zabranial wznawiania sprawy, jeżeli wyrok był wydany zgcdnie przez wszystkich

3 Zob. c. 1-40, C. II, q. 6. - Mamy tu zebrane przez Gracjana starożyitne źródła dotyczące apelacji kanonicznej.

${ }_{4}$ C. 9, C. II, q. 6: „Placuit, ut a quibuscumque ecclesiasticis iudicibus ad alios iudioes ecclesiasticos (ubi est maior auctoritas) provocatum fuerit, audientia non negetur".

$5 \mathrm{~J}$. G a u de me t, L'Eglise dans l'empire romain (IVe-VI $I^{\mathrm{e}}$ siècle), t. III, Paris 1958 , s. 250-252.

6 C. 32 , C. II, q. 6: „Catholicus, qui causam suam, sive iustam sive iniustam, ad iudicium alterius fidei iudicis provacat excommunicetur".

7 C. 27, C. II, q. 6: „Omnimodo puniendus est, quaciens iniusita appellatio pronunciatur..."

8 Breviarium fidei. Kodeks doktrynalnych wypowiedzi Kościola, oprac.

J. M. S z y m u s i a k i S. G 1 o w a, Poznań 1964, s. 65-66.

9 Tamże, s. 66, n. 3.

10 Tamże, s. 68, n. 5.

11 Kazanie 131. PL 38, 734. 
biskupów prowincji 12. Było zasadą, że nie należy zmieniać decyzji rozumnie podjętych ${ }^{13}$. Gracjan pod wpływem prawa rzymskiego głosił zasadę, że w tej samej sprawie nie wolno apelawać więcej niż dwa razy 14. Przytacza on jednak przepisy, które nie ograniczają apelacji pod względem liczebnym ${ }^{15}$. Dekretyści i dekretaliści zajmowalli $\mathrm{w}$ tej sprawie różne stanowiska ${ }^{16}$. Prawo dekretałowe dostarczyło podstaw do głoszenia zasady potrójnego zgodnego wyroku (triplex sententia conformis) 17. Jednakże pod wplywem orzecznictwa trybunałów świeckich, a następnie Roty Rzymskiej, w drugiej polowwie XVI wieku do sądownictwa kościelnego zaczęła przenikać zasada podwójnego zgodnego wyroku (duplex sententia conformis) 18. Zasadę tę $\mathrm{w}$ odniesieniu do spraw o nieważność małżeństwa usankcjonowal Benedykt XIV w Konstytucji Dei miseratione z dnia 3 listopada 1741 r. ${ }^{19}$ Tenże papież wykluczył możliwość zawarcia nowego małżeństwa już po puierwszym wyroku orzekającym nuieważność małżeństwa, co dotąd mogło się zdarzyć, jeśli strona pozwana zaniechała apelacji; odtąd są konieczne dwa zgodne wyroki. Obowiązkiem wniesienia apelacji z urzędu od każdego wyroku po raz pierwszy orzekającego mieważność małżeństwa został obarczony obrońca węzła małżeńskiego. Ta zasada pozostała niezmieniiona do czasów dzisiejszych ${ }^{20}$.

\section{b. Pojęcie apelacji}

Termin ,apelacja” (appellatio) wywodzi się od słowa łacińskiego appello (= wołam, prosze o pomoc, odwołuję się). Oznacza on prawne odwolanie się strony, któna uważa się za pokrzywdzoną wyrokiem ssądowym, do sędziego wyższego czyli do sądu ıwyższej instancji (zob. kan. 1628).

12 C. 5 , C. VI, q. 4.

13 C. 1 , C. $\times \times \times V$, q. 9.

14 C. 39, C. II, q. 6: "Tertio in una eademque causa super hisdem capitulis provorare non "licet". - Zob. T. P i e r onek, Zakaz trzeciej apelacji $w$ Dekrecie Gracjana. Analecta Cracoviensia 7 (1975) 403-410; tenże, "Res iudicata" a niezmiennośc wyroku $w$ sprawach matżeńskich u Gracjana, Prawo Kan. 20 (1977) nr 1-2, s. 259-266.

15 C. 5-6, C. II, q. 6; c. 6, C. III, q. 6 .

${ }_{16}$ Zob. T. P i e r on ek, Zakaz trzeciej apelacji $i$ niezmienność wyroku w sprawach mażeńskich u dekretystów, Prawo Kan. 20 (1977) nr $3-4$, s. $187-194$.

17 C. 1, II, 11, in Clem. - Zob. T. P i ronek: ,Triplex sententia conformis" $w$ prawie dekretalów, Analecta Cracoviensia 8 (1976) 277294.

${ }^{18}$ T. Pieronek, „Duplex sententia conformis” $w$ sprawach o nieważnośc malżeństwa $w$ prawie kanonicznym. Studium historyczno-prawne, ATK 1975 (maszynopis), s. 54-60.

19 Fontes, I, n. 3i18. - Zob. też Konst. Si datam, 4 III 1748. Fontes, II, n. $385, \S 12$ i 13 , s. $136-137$.

${ }_{20}$ Zab. M. M anga n, „Res iudicata”. An Historico-Judical Study, 
Celem apelacji jest spowodowanie ponownego rozpatrzenia sprawy, a tym samym uchylenie lub amiana wyroku wydanego przez sąd niższej instancji, niekorzystnego dla strony apelującej. Podstawą apelacji jest przeświadczenie strony, że wyrok wydany przez sędziego niższego jest dla niej krzywdzący nie tylko subiektywnie, lecz także obiektywnie, a więc jest niesprawiedliwy.

Wyrok może się stać niesprawiedliwy $\mathrm{z}$ wielu powodów. Może on naruszać interes strony na skutek naruszenia prawa materialnego. Naruszeniie to może nastąpić $\mathrm{w}$ wyniku błędnej wykładni lub niewłaściwego zastosowania prawa materialnego w konkretnej sprawie sądowej. Niesprarwiedliwy jest wyrok, jeśli wlaściwie pojęte prawo materialne zostało zaaplikowane do niewłaściwie ustalonego stanu faktycznego. Wyrok może być krzywdzący $w$ razie niewyjaśnienia okoliczności faktycznych, istotnych dla rozstrzygnięcia sprawy 21.

W wyniku apelacji wyrok poprzedniej instancji może być zatwierdzony, uchylony lub poprawiony. Apelujący nie może mieć absolutnej pewności, że sprawę wygra; każda apelacja stanowi dla apelującego pewne ryzyko.

Prawo do apelacji przysługuje stnonie zarówno powodowej jak i pozwanej. Jedna i druga strona może poczuć się polksrzywdizona wyrokiem sądowym. Rzadko się zdarza, aby wyrok zadowolił obie strony jednocześnie; najczęśsiej $\mathrm{z}$ wyroku jest zadorwolona tylko jedna strona, natomiast druga, jeśli nie ze względów obiektywnych, to przynajmmiej subiektywnie, jest przekonana o krzywdzącym, a więc niesprawiedliwym rozstrzygnięciu przedłożonej sprawy. Tylko w odniesieniu do spraw karnych i spraw o roszczenia cywilne wyrok o charakterze kompromisowym może niekiedy zadowolić obje strony, w rwiązku z czym rezygnują z dalszego sporu, wyrok zaś pierwszej instancji staje się prawomoony po upływie czasu przemnaczonego ma apelację (zob. kan. 1641 n. 2), czyli po upływie piętnastu dni użytecznych od wiadomoścí o ogłoszeniu wyroku (zob. kan. $1630 \S 1$ ).

Pewną specyfike pod tym względem maja sprawy o nieważność małżeństwa. Doświadczenie uczy, że nie tylko strona powodowa, lecz takize strona pozwana jest zainteresowana wyrokiem orzekającym mieważność małżeństiwa, gdyż obie strony dzięki pozytywnemu wyrokowi mogą zawrzeć nowe związki małżeńskie. W takim razie przed sądem staje obrońca węzła małżeńskiego. Jako rzecznik świętości a nienozenwalności węzła małżeńskiego przedkłada on żądanie, aby raz jeszcze mozważyć, czy $\mathrm{w}$ świetle przedstawionych argumentów nie da się uratować zaskarżonego malżeństwa.

Rome 1962; L. M usselli, Il concetto di giudicato nelle fonti storiche del diritto canonico (Dalle origini al XVII secolo), Padova 1972.

${ }_{21}$ Zob. T. Pawluk, Kanoniczny proces malżeński, Warszawa 1973, s. 161 . 
Oprócz stron i abrońcy węzła małżeńskiego apelację od wyroku w sprawach o niewaizność małżeństwa może wnieść publiczny oskıarżyciel czyli promotor sprawiedliwości (zab. kan. 1628), jeśli zgodnie z prawem zaskarżył ważość małżeństwa (zob. kan. 1674 n. 2).

Apelacja nie jest jedynym środkiem prawnym służącym do zwalczania wyroku. Środkami odwolawczymi są ponadto skarga o nieważność wyroku (querela nullitatis) oraz - gdyby chodziło o sprawy, które prizechodzą w stan rzeczy osądzonej - prośba o przywrócenie do stanu poprzedniego (restitutio in integrum). Skarga o nieważność 'wyroku mogłaby mieć miejsce w razie naruszenia lub pominięcia przez sąd istotnych pmzepisów proceduralnych lub dotyczących zewnętrznej formy wyroku (zob. kan. 1619-1627), matomiast przywrócenie do stanu popirzedniego - w razie wykrycia, że wyrok ponad wszelką wątpliwość jest niesprawiedliwy (zob. kan. 1645-1648). Sprawy o nieważność małżeństwa nie przechodza w stan rzeczy osądizonej (zob. kan. 1643), dlatego przeciwko nim nie przysługuje restitutio in integrum; przysługuje natomiast $w$ określonych warunkach tzw. nova causae propositio (zob. kan. 1644).

\section{Zgloszenie i poparcie apelacji}

\section{a. Apelacja z urzędu}

Apelację $z$ urzędu do procesu o nieważność małżeństiwa wprowadził Benedykt XIV. Papuież ten IW znanej Konstytucji Dei miseratione $\mathrm{z}$ dinia 3 listopada 1741 r. ustanowił urząd obrońcy węzła małżeńskiego, którego szczególniejszym obowiązkiem było wnoszenie apelacji od wyroku po raz pierwszy or:zekającego nieważność małżeństwa 22. Dzięki zarządzeniu Benedykta XIV wyrok pierwszej instancji arzekający mieważność małżeństwa, a także wyrok instancji wyższe: po raz pierwszy orzekający tę nieważność, nie mógł stać się prawomacny, jeśli nie został potwierdzony wyrokiem kolejne i instancji. Obowiązek apelacji $z$ urzędu w znacznej mierze przyczynił się do tego, ze proces o nieważność małżenstwa wyodrębnil się z procesu ogólnego i stał się procesem szczególnym. Wyparda tu zauważć, że to przede wszystkim sytuacja w Polsce —

$22 \S 8$ : „Itaque si a iudrice pro matrimonii validitate iudicabitur et mullus sit qui appellet, ipse etiam ab appellatione se abstineat; idque etiam servetur, si a iudice secundae instantiae pro validitate matrimanii fuerit iudicatum, postquam iudex primae instantiae de illius nullitate sententiam pronuntiaverit; sin autem contra matrimonii validitatem sententia feratur, defensor inter legitima tempora appellabit adhaerens parti, quae pro validitate agebat; cum autem in iudicio nemo unus sit qui pro validitate matrimonii negotium insistat, vel si adsit, lata contra eum sententia, iudicium deseruerit, ipse ex officio ad superiorem iudicem provocabit". Fontes, I, n. 318 , s. 698. 
jak to obszernie uzasadmia $\mathbf{S}$. Biskupski — wpłynęła na podjęcie decyzji przez Benedykta XIV co do udziału obnońcy węzła w procesie o nieważność małżeństwa i jego obowiązku apelacji 23.

Dyspozycje Benedykta XIV dotyczące obowiązku apelacji obrońcy węzła małżeńskiego znalazły się w Kodeksie Prawa Kanonicznego z 1917 r. ${ }^{24}$, a następnie w Instrukcji Provida Mater Ecclesia Kongregacji Saknamentów z dnia 15 sierpnia 1936 r. 25 oraz w Motu propmio Causas matrimoniales Pawła VI z dnia 28 marca 1971 r. ${ }^{26}$

Pewną mowość do postępowania apelacyjnego wprowadził Kodieks Prawa Kanonicznego z 1983 r. Kodeks ten zobowiązuje do przesłania $z$ urzędu zarówno wyroku, który po raz pierwszy orzekł nieważność małżeństwa, jak i apelacji, jeśli wpłynęły, wraz z aktami sądowymi, w ciągu diwudziestu dini od ogłoszenia wyroku, do trybunału apelacyjnego 27.

A więc nowy Kodeks Prarma Kanonicznego nie nakazuje dokonania apelacji obrońcy węzła małżeńskieg,o, jak to było dotąd, lecz poleca trybunałowi a quo przesłanie wyroku $z$ aktami i ewentualnymi apelacjami do trybunału apelacyjnego $z$ urzędu, tzn. niezależnie od wpłynięcia apelacji. Owszem, obrońca węzła małżeńskiego ma prawo do wniesienia apelacji (zob. kan. 1628), nie ma jednak obowiązku apelowania, ponieważ wyrok z urzędu podlega apelacji. Obrońca węzła może w czasie przepisanym zgłosić apelację; gdyiby jednak tego mie uczynił, sędzia nie musi mu przypominać o ciążącym na nim obowiązku apelacji, jak to czynił dotychczas, lecz powinien przed upływem dwudziestu dni od ogłoszenia wyroku orzekającego nieważność małżeństwa, w ramach własnych czynności, przekazać sprawę instancji apelacyjnej.

Można zapytać, czym kierowal się prawodawca lagodząc dotychczasowy obowiązek obrońcy węzła co do apelacji? Odpowiedź wydaje się proste. Obrońca węzła swoje stanowisko, poparte motywami prawnymi i faktycznymi, przedstawia w uwagach przedwyrokowych (zob. kan. 1601-1603). Odwołując się dó instancji wyż-

${ }^{23} \mathrm{~S}$. B isk upski, Obrońca węzta $w$ kanonicznym procesie matżénskim, Eódź 1937, s. $74-77,98$ n.

${ }^{24}$ Codex Iuris Canonici Pii X Pontificis Maximi iussu digestus, Benedicti Papae XV auctoritate promulgatus (= CICB), kan. 1986: ,A prima sententia, quae matrimonii nullitatem declaraverit, vinculi defensor, intra legitimum tempus, ad superius tribunal provocare debet; et si negligat officium suum implere, compellatur auctoritate iudicis".

${ }_{25}$ Instructio servanda a Tribunalibus Dioecesanis in pertractandis causis de nullitate matrimoniorum, art. $212 \S 2$. AAS 28 (1936) 313.

${ }^{28}$ Litterae Apostolicae Motu proprio datae quibus normae quaedam statuuntur ad processus matrimoniales expeditius absolvendos, n. VIII $\S 1$. AAS $63(1971) 441$.

27 Kan. 1682 § 1: „Sententia, quae matrimonii nullitatem primum declaraverit, una cum appellationibus, si quae sint, et ceteris iudicii actis, intra viginti dies a sententiae publicatione ad tribunal appellationis ex officio transmittatur". 
szej powtórzyłby tylko argumenty już przytoczone. $Z$ tych wlaśnie względów od dawma wytworzył się zwyczaj, że obrońcy węzla czynili zadość obowiązkowi apelowania przez samo zgłoszenie apelacji, z pominięciem jej poparcia 28. Gdyby jednak obrońca węzła $\mathrm{w}$ międzyczasie zdobył nowe argumenty za ważnością danego małżeństwa, powinien apelację poprzeć, skierowując do insitancji apelacyjnej osobne pismo, zgodnie $z$ przepisem $k a n$. 1633 . W ten sposób procedura apelacyjna ma szansę pozbyć się czystej formalistyki.

Niezależnie więc od zgloszenia i poparcia apelacji przez obrońce węzła małżeńskiego trybunał pierwszej instancji, który wydał wyrok orzekający nieważność małżeństwa, a także trybunał inistancji wyższej, jeśli po raz pierwszy orzekł nieważność małżensstwa w wyniku apelacji strony powrodowej, jest obowiązany na mocy prawa przesłać całą sprawę do ponownego rozpatrzenia do instancji apelacyjnej czyli do trybunału, który zgodnie z przepisami prawa procesowego jest uprawniony do przyjęcia apelacji.

Przekazanie sprawy trybunalowi apelacyjnemu porwinno się odbyć $\mathrm{w}$ ciągu dwudziestu dni od ogłoszenia wyroku. Ogłoszenie to może się odbyć albo przez wręczenie stronom lub ich pelnomocnikom odpisu wyroku, albo przez przesłanie tegoż odpisu w sposób udokumentowany stronom lub ich pełnomocnikom (zob. kan. 1615, $1682 \S 1$ ). Dnia wręczenia bądź otrzymania wyroku nie wlicza się, gdyż dzień ten nie pokrywwa się $z$ początkiem dnia. Dlatego pierwszym dniem, który wwlicza się do czasokresu dwudzziestu dni, jest dzień następny po dniu, w którym odbyło się wręczenie lub dostarczenie odpisu wyroku (zob. kan. 203 § 1).

\section{b. Apelacja strony powodowej}

Jest rzeczą oczywistą, że strona powodowa wnosi apelacię do wyższej instancji tylko $\mathrm{w}$ razie wydamia pnzez sąd pierwszej instancji, ewentualnie przez sąd drugiej instancji, wyroku negatywnego, tj. orzekającego ważność małżeństwa. Strona powodowa nie musi apelować do instancji wyższej; może pogodzić się z wyrokiem negatywnym i uznać jego sprawiedliwośc. W takim razie sprawa zostaje zakończona na szczeblu instancji pierwszej, ewentualnie drugiej, która nie potwierdziła pozytywnego wyroku instancji pierwszej. Tylko wyrok pozytywmy, tj. po raz pierwszy orzekający nieważność małżeństwa zgodnie $z$ żądaniem strony powodowej, podlega apelacji z urzędu.

Appelacja strony powodowej jest czynnością złożoną. Obejmuje ona zgłoszenie jej $\mathrm{w}$ trybunale, który wydal wyrok (interpositio appellationis), craz poparcie jej w trybunale wyższym (prosecutio

28 T. P a w luk, Kanoniczny proces maţ̇eński, s. 165. 
appellationis). Tak byla pojmowana apelacja również w świetle przepisów poprzedmiego Kodeksu Prawa Kanonicznego ${ }^{29}$.

Apelację należy zgłasić w trybunale, który wydał wyrok niekorzystny dla strony powodowej, w ciągu piętnastu dni użytecznych od otrzymania wiadomości o ogłoszeniu wyroku ${ }^{30}$. Okres piętnastu dini należy liczyć zgodnie $z$ zasadą zawartą $w$ przepisie kan. $203 \S 1$. Piętnaście dni to czasokres nieprzekraczalny (terminus peremptorius). Jednakże nie płynie on, jeśli strona nie wie, że na wniesienie apelacji jest przeznaczonych piętnaście dini, albo wie o tym, lecz w wyznaczonym czasokresie nie może działać (zob. kan. 201 § 1), inp. z powodu choroby, nieobecności w kraju, przebywania $w$ więzieniu itd.

Porównując powyższą dyspozycję odnowionego prawa procesowego $z$ odpowriednim przepisem Kodeksu Prawa Kanonicznego $z$ 1917 r. dostrzegamy różnicę. Poprzednie prawo procesowe na zgłoszenie apelacji przeznaczało tylko dziesięć dni, nie określając charakteru tych dni ${ }^{31}$, matomilast nowe prawo procesowe termin przeznaczony na apelację wydłużyło do piętnastu dini, podkreślając, że sa to dni. nieprzekraczalne, a jednocześnie użyteczne. Wydłużenie tego terminu zostało padyktowane interesem strony. Praktyka procesowa wykazała, ze czasokres dziesięciu dni jest niekiedy zbyt krótki na podjęcie decyzji o zgłoszeniu apelacji i dopelnienie formalności związanych $\mathrm{z}$ tym zgłoszeniem. Jeślji strona dokona zgloszenia apelacji w krótszym terminie, tym samym przyczyni się do szybszego nadanlia dalszego biegu sprawie.

Apelację zwyczajnie składa się na piśmie. Wystarczy napisać: „Od wyroku Sądu Biskupiego Diecezji... z dinia..., orzekającego ważność małżeństwa N.-N., odwołuję się do Sądu Metropolitalnego w ... jako Trybunału II Instancji", podając miejsce i dzień zgloszenia apelacji. Notariusz sądowy na piśmie tym sporządzi adnotację o dacie jego faktycznego dostarczenia, ewentualnie wysłania przez pocztę (data stempla).

Można jedinak apelację zgłosić usinie, np. bezpośrednio po otrzymaniu $w$ sądzie odpisu wyroiku. W takim razie notariusz jest obowiązany fakt zgłośzenia apelacji zaprotokołować w obecności strony apelującej (zob. kan. $1630 \S 2$ ) oraz pouczyć stronę o konsekwencjach tego zgłoszenia.

Niekiedy przy zgłaszaniu apelacji może się zrodzić wątpliwość co do przysługiwania stronie prawa do apelacji. Sprawe de iure appellandi rozpatruje $w$ jak majkrótszym czasie (expeditissime)

29 CICB, kan. $1881-1884$.

${ }^{30} \mathrm{Kan} .1630 \S 1$ : „Appellatio interponi debet coram iudice a quo sententia prolata sit, intra peremptorium terminum quindecim dierum utilium a notitia publicationis sententiae".

31 CICB, kan. 1881. 
trybunał apelacyjny według norm ustnego procesu spornego (kan. 1631), zawartych w kanonach 1656-1670. Od decyzji trybunału apelacyjnego $\mathrm{w}$ sprawie prawa do apelacji nie przysługuje dalsze odwolanie (zoib. kaan. 1629 n. 5).

Zgłoszona apelacja wywrze skutki prawne, jeśli zostamie przez stronę poparta w sądzie apelacyjnym. Poparcia tego należ dokonać iw ciągu miesiąca od zgłoszenia apelacji, chyba że trybunał a quo wyznaczył dłuższy czas na jej poparcie (kan. 1633). Czasokres miesięczny należy liczyć według zasady przepisanej w kan. $203 \S 2$. Miesiąc kończy się z upływem dnia o tej samej liczbie, a jeżeli miesiąc nie ma dnia o tej liczbie $-z$ upływem ostatniego dnia miesiąca.

$\mathrm{Na}$ poparcie apelacji nie trzeba przytaczać szczegółowego uzasadnienia. Wystarczy, jeśli strona zwróci się do trybunalu apelacyjnegio $z$ żądaniem zmiany wyroku wydanego przez trybunał niż̇zy, załączając odpis tego wyroku i wskazując na racje apelacji (kan. 1634 \& 1 ).

Termin przeznaczony na poparcie apelacji nie biegnie, jeśli sąd niższej instancji nie wydał $w$ porę odpisu wyroku. W takim razie o zwłoce w wystawieniu odppisu wyroku należy powiladomić trybunał apelacyjny, który sędziego a quo zobowiąże nakazem do sppelnienila swojego obowiązku (kan. 1634 § 2). Strona nie musi swojego egzemplarza odpisu wyroku, który otrzymaka w związku $\mathrm{z}$ ogłoszeniem wyroku, przesylać do trybunału apelacyjnego.

Terminy apelacyjne to terminy zawite. $\mathrm{Z}$ niezachowaniem ich ustawa wiąże ujemne skutki dla strony. Niedostosowanie się do tych terminów oznaczałoby, że apelacja została zaniechana ${ }^{32}$.

Apelacja wniesiona przez stronę powodową przysługuje stronie pozwanej, i odwnatmie (kan. 1637 § 1). Oznacza to, ze nue tylko strona apelująca, lecz także strona przeciwna jest podmiotem działanila $w$ instancji apelacyjnej.

Apelacja może dotyczyć całego wyroku albo tylko jego części. Domniemywa się, że apelacja, jeśli co innego na pewno nie wynika, dotyczy całego wyroku, a więc wszystkich jego punktów ${ }^{33}$. Ale nic nie stoi na przeszkodzie, aby strona apelowała tyliko od części wyroku, np. tej części, któna orzeka o wysokości kosztów sądowych albo obowiązkach moralnych bądź cywilnych wabec drugiej strony i dzieci.

32 Kan. 1635: „Inutiliter elapsis fatalibus appellatoriis sive coram iudice a quo sive coram iudice ad quem, deserta censetur appellatio". s3 Kan. $1637 \& 4$ : „Nisi aliud constet, appellatio praesumitur facta contra omnia sententiae capita". 


\section{Przeslanie akt do trybunalu apelacyjnego}

\section{a. Formalności}

Trybunał, który wydał wyrok podlegający apelacji z urzędu zgodnie $\mathrm{z}$ przepisem kan. $1682 \S 1$, jest obowiązany w ciągu dwudziestu dni przesłać akta do instancji apelacyjnej; terminem a quo jest dzień ogłoszenia wyroku (zob. kan. $1682 \S 1$ ). Jeśli zaś od wyroku negatywnego apeluje strona powodowa, akta należy przeslać w ciągu miesiąca od zgłoszenia apelacji. Chyba że sąd a quo zgodził się na poparcie apelacji w czasie dłużs:zym niż miesięczny; w takim razie akta przesyła się przed upływem tego terminu (zob. kan. 1633, $1634 \S 3$ ).

Jeśli apelacja zostaje wniesiona $z$ urzędu, trybunał a quo przesyła do instamcji apelacyjnej: wynok orzekający nieważność małżeństwa, ewentualne odwołania, np. obrońcy węzła bądź strony pozwanej, oraz pozostałe akta sądowe (kan. 1682 § 1). Jesli wyrok jest zwalczany przez stronę powodową, do instancji aipelarcyjnej również przesyła się całość akt sądowych, z tym jednak, że strcna ta może asobno przesłać pismo popierające apelacje 'wraz $z$ odpisem wyroku (zoib. kan. 1634).

Do trybunału opelacyjnego z zasady przesyła się odpis akt (actorum exemplar), którego autentyczność potwierdza notariusz ${ }^{34}$. Akta oryginalne powinny pozostać $w$ trybunale a quo. Jest to zrozumiałe, jeśli weźmie się pod uwagę możliwość zaginięcia akt orygunalnych podczas przesyliania ich drogą pocztową. W razie zaginięcia tych akt niemożliwe byłoby odtworzenie procesu; a więc strata byłaby niepowetowana.

$\mathrm{Z}$ drugiej jednak strony sporządzenie odpisu akt to czynność wymagająca dużego nakładu pracy i czasochłonna, nie zawsze dająca się przeprowadizić w przepisanym czassie. Dlatego w polskim orzecaznictwie kościelnym wytworzył się zwyczaj przesyłania do trybunału apelacyjnego akt oryginalnych, jeśli - zważywszy na sposób przesłania - zachodzi pewność, że akta oryginalne zostaną bezpiecznie przesłane i bezpiecznie powrócą. Nic jednak nie stai na przeszkodzie, aby akta od początku były sporządzane w dwóch jednobrzmiących egzemplarzach, czyli akta oryginalne i w odpisie; tym bardziej, że odpisy można sporządzać metodą kserograficzoną.

Przesyłane akta muszą być spięte w sposób trwały, aby uniemożliwić wypadnięcie jakiegoś dokumentu bądź jego usunięcie lub zamianę. Ponadto poszozególne karty akt mają być ponumerowane i sygnowane jako autentyczne ${ }^{35}$. Całość akt powinna być na koń-

${ }^{34} \mathrm{Kan} .1474$ § 1: „In casu appellationis, actorum exemplar, fide facta a notario de eius authenticitate, ad tribunal superius mittatur".

${ }^{35} \mathrm{Kan} .1472 \S 2$ : „Singula folia actorum numerentur et authenticitatis signo muniantur". 
cu poświadczona przez notariusza. Powinien też być sporządzony wykaz wszystkich akkt i dokumentów.

Gdyby akta były sporządzone iw języku nie znanym trybunałowi apelacyjnemu, np. Rocie Rzymskiej, należałoby je przetłumaczyć na język temuż trybunałowi znany, przy czym należy mieć pewność, że tłumaczenie jest wiène ${ }^{\mathbf{3 6}}$. Kongregacja Sakramentów w swej Instrukcji Provida z 1936 r. domagała się, aby tłumacz, jeśli został specjalnie powołany, złożł przysięge, że wiernie spełni powierzone sobie zadanie i zachowa tajemnicę ${ }^{37}$. Zgodność thumaczenia z aktami oryginalnymi powinien poświadczyć notariusz lub kanclerz.

Przesyłając akta notariusz porwinien skierować do trybunału apelacyjnego odpowiednie pismo towarzyszące.

\section{b. Trybunat apelacyjny}

Jest zasadą, że drugą instancją dla trybunałów diecezjalnych jest trybunal metropolity (kan. 1438 n. 1), natomiasit dla trybunału metropolity, orzekającego sprawy $w$ pierwszej instancji, trybunał obrany przez metropolitę ina stałe za aprobata Stolicy Apostolskiej (kan. 1438 n. 2).

Instancją apelacyjną jest też Trybunał Roty Rzymskiej. Rota Rzymskka sądzi sprawy w drugiej instancji, jeśli wpłynęły one do Stolicy Apostolskiej po osądzenliu ich przez zwyczajny trybunał pierwszej instancji (kan. $1444 \S 1 \mathrm{n} .1$ ). Sądzzi też w trzeciej i dalszej instancji sprawy już rozpatrzone przez siebie lub inne trybunały (kan. 1444 § 1 n. 2).

Gdyby wyrok został wydany przez trybunał międzydiecezjalny, a więc ustanowiony po myśli kan. 1423, instancją apelacyjną byłby trybunał ustanowiony przez Konferencję Biskupów za aprobata Stolicy Apostolskiej; chyba ze wszystkie diecezje byłyby sufragamiami tej samej archidiecezji (kan. 1439 § 1). Konferencja Biskupów może za aprobatą Stolicy Apostolskiej ustanowić jeden lub więcej wspólnych trybunałów apelacyjnych, niezależnie od istnienia międzydiecezjalnych trybunałów pierwszej instancji (kan. $1439 \S 2$ ).

Kodeks Prawa Kanonicznego z 1917 r. mie znał trybunałów wspólnych - ani pierwszej, ani drugiej instancji. Pojawiły się one za zgodą Stolicy Apostolskiej najpierw we Włoszech 38, później w innych krajach ${ }^{39}$. Powszechnie zostały usankcjonowane przez

36 Kan. 1474 \& : "Si acta exarata fuerint lingua tribunali superiori ignota, transferantur in aliam eidem tribunali cognitam, cautelis adhibitis, ut de fideli translatione constet".

${ }^{37}$ Art. $105 \& 2$.

38 Zob. AAS 30 (1938) $410 \_413 ; 32$ (1940) $304 \longrightarrow 308$. 
Najwyższy Trybunal Sygnatury Apostolskiej w 1970 r. 40 Nie ulega wątplímości, że dzięki trybunałom wspólnym, dobrze zorganizowanym i sprawnie funkcjonującym, można lepiej i szybciej rozpatrywać sprawy sądowe, zwłaszcza małżeńskie, któne nie cierpią zwłoki. Trybunały te $w$ ostatnich czasach sa przedmiotem zainteresowań biskupów mniejszych diecezj.i 41.

W Kościele katolickim w Polsce, obok trybunałów apelacyjnych ustanowionych zgadnie $z$ prawem powszechnym ${ }^{42}$, istnieją trybunały trzeciej instancji, ustanowione na mocy specjalnego indultu ${ }^{43}$. Nie przeszkadza to jednak $w$ apelowaniiu bezpośrednio do Roty Rzymskiej.

Wypada tu jednaik zauważyć, że sprawy małżeńskuie, osądzone $w$ polskich sądach kościelnych w pierwszej lub drugiej instancji, bardzo rzadko są przekazywane $\mathrm{w}$ trybie apelacyjnym do Stolicy Apostolskiej. Zadecydowała o tym przede wszystkim trudność w kontaktowaniu się $\mathrm{z}$ Rotą Rzymską oraz $\mathrm{w}$ ustanawianiu pelnomocników i adwokatów w Rzymie.

\section{Zakończenie}

Prawa do apelowania, czyli do odwołania się do sędziego wyższego od wyroku wydanego przez sędziego niższego, mie jest łaską przyznaną stronom procesującym się przez ustawodawcę. Prawo to wyplywa $z$ pnawa natury. Prawo naturalne domaga się, aby

${ }^{39}$ Zab. I. Gordon, De tribunalibus regionalibus cum respectu ad iudicum delectum et ad processus breviationem, Periadica de re morali, canonica, liturgica 56 (1967) $580-586$.

40 Normae pro Tribunalibus interdioecesanis vel regionalibus aut interregionalibus, 28 XII 1970. AAS 63 (1971) 486-492.

${ }_{41}$ T. P a w l u k, Kanoniczny proces matzeński, s. 188.

42 Polskie trybunały kościelne drugiej instancji: 1) trybunał metropolitalny w Warszawie - dla sądów diecezji lubelskiej, lódzkiej, płockiej, podlaskiej, sandomierskiej i warmińskiej; 2) trybunał metropolitalny iw Gnieźn'i e - dila sądu archidiecezjo proznańiskiej oraz sądów diecezji chełmińskiej, koszalińsko-kołobrzeskiej, szczecińsko-kamieńskiej i wlocławskiej; 3) trybunal metropolitalny w K rakow ie - dla sądów diecezji częstochowskiej, katowickiej, kieleckiej, tarmowskiej oraz, na podstawie specjalnego indultu, dla własnych spraw; 4) trybunał metropolitalny w Poznan i u - dla sądów archidliecezji gnieźnieńskiej, warszawskiej i wrocławskiej oraz sądu w Lubaczowie; 5) trybunał metropolitaliny we W r o c ła w i u - dla sądów diecezji gorzowskiej i opolskiej; 6) trybunał archidiecezji w B i a ł y m s tok u — dla sądu diecezji łomżyńskiej; 7) trybunał diecezji l ubelskiej-dla sądu diecezji przemyskiej; 8) trybunal die ce zj i lomżyński e j - dla sądu archidiecezji w Bialymstoku. - Zob. T. P a w luk, Kanoniczny proces matżenski, s. 162.

${ }_{43}$ Zob. Dekret Prymasa Polski z dnia 22 X 1960 r. w sprawie właściwości terytorialmej Sądów III Instancji w Polsce. - J. G le m p, Polskie sqdownictwo kościelne w latach 1945-1970, Prawo Kan. 14 (1971) nr $3-4$, s. $169-187$. 
każdemu, kto czuje się pokrżywdzony wyrokiem, zezwolono dochodzić sprawiedliwości.

Prawo do apelowania ma charakter obiektywny, co oznacza, że sędzia musi $z$ urzędu to prawo uznać i przyczynić się do jego realizacji. Sędzia jest zobowiązany do rzetelnego pouczenia stron o przysługującym im prawie do odwołania się do instancji rwyższej zgodnie z przepisami prawa procesowego.

Sprawy o nieważność malżeństwa mają charakter specyficzny. Żądanie orzeczenia mieważności małżeństwa niekiedy wypływa $\mathrm{z}$ motywów subiektywnych strony powadowej. Ząadanie to zwykle popiera strona pozwana, gdyż dzięki wyrokowi pozytywnemu ona również będzie mogła zawrrzeć nowy związek małżeński. Tymczasem sprawa węzła małżeńskiego nie może być rozstrzygnięta umownie. U podstaw wyroku orzekającego nieważność małżeństwa musi leżeć prawda obiektywna, a więc przeszkoda rorzywająca, wada zgody małżeńskiej bądź niezachowanie kanonicznej formy zawarcia małżeństwa. Aby wyeliminować ewentualnie niedociągnięcia w poszukdiwaniu prawdy obiektyrwnej, wyrok po raz pierwszy orzekający nieważność małżeństwa podlega apelacji z urzędu.

Instytucja apelacji nie może demobildizująco wpływać na sędziego niższego przy poszukiwaniu prawdy obiektywnej. Nie może on zakładać, że wszystkie jego niedociągnięcia zostaną naprawione w sądzie apelacyjnym. Tylko połączone wysitki dwóch instancji dojścia do prawdy dają gwarancję, że wyrok będzie sprawiedliwy. Apelacja daje okazję do sprawdzenia, czy wysiłek podjęty przez instancję nizszą był rzetelny i odpowiedzialny.

\section{De iure appellandi \\ in causis ad matrimonii nullitatem declarandam}

Appellatio est provocatio ab inferiore iudice, qui sententiam tulit, ad superiorem, ad impugnatae sententiae emendationem. Distinguitur appellatio ex officiol iudicils et ad instantiam partis.

Sententia, quae matrimonii nullitatem primum declaraverit, una cum appellationibus, si quae sint, et ceteris iudicii actis, intra viginti dies a sententiae publicatione ad trbunal appellatonis ex officio transmittatur. Defensor vinculi habet ius a sententia matrimonii nullitatem primum declarantem alppellandi ad iudicem superiorem, sed ad appellandum ex officio mon tenetur; acta enim ex officio ad tribunal appelilationis transmittantur.

Ius appellandi ad iudicem superiorem habet pars, quae sententia negativa se gravatam putat. Appellatio interponi debet coram iudice a quo sententia prolata sit, intra peremptorium terminum quindecim dierum utilium a notitia publicationis sententiae. Prosecutio appellationis dirigitur ad iudicem superiorem intra mensem ab interpositione, nisi iudex a quo longius tempus ad eam prosequendam parti praestituerit.

Appellatio quoad substantiam derivat a iure naturae, quoad formam a iure canonico positivo. 